\title{
Research on E-commerce Logistics Mode of Halal Agricultural Products in Ningxia
}

\author{
Haiying $\mathrm{Ma}^{1, \mathrm{a}^{*}}$, Hui Zhang ${ }^{2, \mathrm{~b}}$ \\ ${ }^{1,2}$ The Provincial Key Laboratory of E-commerce of Ethnic Information, School of Economics, Northwest \\ Minzu University, Lanzhou (730124), P.R.China \\ axmahaiying8888@163.com, b24060565 @qq.com
}

Keywords: E-commerce; Logistics mode; Halal products; Ningxia

\begin{abstract}
The rapid rise of the rapid development of e-commerce depends on the development of the logistics industry, the logistics industry is also rising due to the electronic commerce, and the two complement each other. The e-commerce of agricultural products logistics modernization is the bottleneck of e-commerce of agricultural products. Halal agricultural products of Ningxia renowned Chinese and foreign, the Ningxia Hui Autonomous Region government attaches great importance to the development of Muslim agricultural products electronic commerce. In order to create the environment for the development of Halal agricultural e-commerce good, promote the development of Muslim agricultural e-commerce, Ningxia urgent development of e-commerce of agricultural products logistics Halal lag problem, based on the analysis of Ningxia Halal agricultural products E-commerce logistics present situation and existing problems and puts forward the logistics mode of E-commerce of agricultural products in Ningxia Halal innovative.
\end{abstract}

\section{Introduction}

Electronic commerce is the trend of modern business flow, information flow and capital flow and efficient operation, but also the virtual economy platform, supply chain logistics is the basic condition of the development of the real economy, only the virtual economy and real economy mutual connection and cooperation can effectively promote the coordinated development of the whole national economy. Model of supply chain logistics of agricultural products E-commerce platform is a product of the combination of virtual and real economy, the establishment of agricultural E-commerce platform is the direct embodiment of carrying out the user oriented, and the logistics mode of agricultural products supply chain is the effective guarantee to improve customer satisfaction. The logistics mode of agricultural products supply chain is the standardization of supply chain logistics, e-commerce platform is matched with the circulation methods, these models need to be empirical, especially agricultural product variety, such as the use of a unified model, may lack the applicability and pertinence. Halal agricultural products of Ningxia renowned Chinese and foreign, the Ningxia Hui Autonomous Region government attaches great importance to the development of Muslim agricultural E-commerce. In order to create the environment for the development of Halal agricultural e-commerce good, promote the development of Muslim agricultural e-commerce, Ningxia urgent development of e-commerce of agricultural products logistics Halal lag problem, based on the analysis of Ningxia Halal agricultural products E-commerce logistics the current situation and existing problems, puts forward the logistics mode of agricultural products of Ningxia Halal E-commerce is innovative.

\section{E-commerce Logistics Characteristics of Halal Agricultural Products in Ningxia}

Effective Guarantee the Quality of Halal Products. Halal agricultural products as a kind of special agricultural products, not only has the characteristics of most agricultural products, but also meet the requirements of Halal food, through the electronic commerce logistics, can avoid the wholesalers and retailers, reduce logistics links, reduce agricultural losses in logistics. Ningxia set up Halal food certification center, the Halal certification can ensure Halal quality of agricultural products. 
Broadening the Sales channels of Halal Products. Through the electronic commerce logistics, agricultural products can be Halal and Arab Economic Forum together, Arabia state as a Muslim, there is considerable demand for Halal agricultural products, through the platform of E-commerce platform, the Muslim Ningxia agricultural products sold abroad. Besides Ningxia, there are many Muslims scattered throughout the country, while under the influence of regional culture, but still maintained the Muslim tradition, through the electronic commerce logistics, so that they can obtain the Halal food certification of agricultural products.

Informatization Requirements for Agricultural Products. Poor circulation of agricultural products, the production and operation of the contradiction between the fundamental reason is that the peasant economy and the large market, big circulation incompatible. The introduction of network technology in agriculture, through e-commerce platform can well solve this contradiction, agricultural informatization is agricultural products supply and demand sides of the bridge, which plays an important role in the application to promote E-commerce in agriculture in the. Ningxia Halal agricultural E-commerce logistics to get rapid development and cannot be separated from the improvement of agricultural information.

Logistics Enterprises and Logistics Infrastructure The improvement of logistics infrastructure can promote the development of local logistics enterprises, thus promoting the development of the local logistics industry, e-commerce and logistics industry are closely related on each other and promote each other. The development of e-commerce logistics of Halal agricultural products in Ningxia is mainly restricted by the scale of logistics, the number of logistics enterprises and the conditions of logistics infrastructure in Ningxia.

\section{Analysis of E-commerce Logistics of Halal Agricultural Products in Ningxia}

Ningxia E-commerce Status of Halal Agricultural Products. Analysis in recent years, in the autonomous region government vigorously develop e-commerce strategic planning driven, Ningxia Halal agricultural e-commerce development rapidly, the growth rate of more than $200 \%$. E-commerce has become an important channel for the industrialization of Halal agricultural products, the expansion of sales income and the promotion of brand in Ningxia. Ningxia Halal agricultural products E-commerce application general situation: Ningxia local Muslim agricultural E-commerce enterprises continue to grow. For example, the Yinchuan Qi Trading Co. Ltd. not only local operations in Ningxia, and began to open up the market in the country, the volume also increased year by year. Second, the awareness of e-commerce of Halal agricultural enterprises in Ningxia has increased continuously. Braim source through self business platform (including enterprise portal), entrust the third party business platform, relying on Taobao, Tmall, Jingdong mall and other electronic business platform to open multiple channels of Halal agricultural products marketing. (3) the online trading volume of Halal agricultural products in Ningxia has been expanding. With the development of agricultural industrialization, the varieties and quantities of online transactions of Halal agricultural products in Ningxia have been expanding. Now, as long as you go to Taobao, Jingdong mall and other E-commerce sites, wolfberry and other agricultural products, you can click on the mouse, you can achieve online trading.

Halal Agricultural Products Logistics Analysis. (1)logistics, social logistics total 405 billion 200 million Yuan, an increase of 26.7\%; the regional logistics industry realized added value of 31 billion 982 million Yuan, calculated at comparable prices, an increase of $10.1 \%$, the region accounted for $13.7 \%$ of GDP, the logistics industry on the growth of the national economy gradually increased; the total social logistics costs 58 billion 500 million Yuan, a year-on-year increase of 3.4\%, the ratio of total logistics costs to GDP was $25.1 \%, 1.8$ percentage points lower than the previous year; the logistics related industry investment in fixed assets of 16 billion 733 million Yuan, an increase of $13.7 \%$ over the previous year. (2) Logistics infrastructure conditions gradually improved. According to the future industrial research center data show that as of the end of 2012, Ningxia highway mileage of $26522 \mathrm{~km}$, an increase of $8.2 \%$, the highway mileage of $1323.6 \mathrm{~km}$, a year-on-year increase of $1.3 \%$; the railway operating mileage of $1029.3 \mathrm{~km}$. From the freight transport situation, in 2012, Ningxia completed 422 million 468 thousand tons of cargo transportation, an increase of $11 \%$; completed turnover of 1101.99 tons of goods, an increase of $14.6 \%$. (3) With the continuous growth of rapid economic and social development in Ningxia and the scale of logistics demand, the rapid increase in the number of enterprises logistics, enterprise structure diversification in.2012 years, the number of road freight industry reached 59176, 7154 increased over the previous year. There are 1047 enterprises registered in the 
industry and Commerce Bureau of logistics, transportation, warehousing and so on, with a total of 126 registered capitals of more than 5 million Yuan. The Ningxia Hui Autonomous Region 12th Five-Year modern logistics industry development plan put forward clearly, to 2015 the foster 1-2 5A brand logistics enterprises, more than $54 \mathrm{~A}$ class $3 \mathrm{~A}$ class logistics enterprises, logistics enterprises reached more than 20 brands, the introduction of foreign advanced logistics enterprises 20.

\section{Analysis of E-commerce Logistics of Halal Agricultural Products in Ningxia}

\section{Environmental Problems of E-commerce of Halal Agricultural Products}

The development of rural economy is backward and the service system of agricultural informatization is not perfect. Ningxia is located in the west of our country, with much land and few people, the network coverage is low, especially in some remote villages, traffic inconvenience, network infrastructure, network speed is low. Residents rarely have the opportunity to contact the agricultural website, it is difficult to access to agricultural information could not meet the demand.

Government as leading role in the construction of agricultural informatization. The government in the agricultural informatization construction is mainly the planning, strengthening legislation, increasing investment, policy, organization and training. At present, although the Ningxia agricultural information network has been running, content is rich, and constantly improve the quality of information, but on the whole, government steps are not unified, the degree of attention and efforts to implement different functions the government in these areas is not obvious.

Agriculture related website construction quality and quantity to be improved. In early 1994, Chinese agricultural information network and Chinese agricultural science and technology information network have been opened, this is a prototype, the development of agricultural E-commerce in China today, the national rural e-commerce site has more than 2000, and the agricultural website has more than 6000 . In recent years, the e-commerce of agricultural products at the unimaginable speed rapid development. The Alibaba Group Research Center released the white paper agricultural e-commerce data show: the management of agricultural products in 2013 Ali sellers on the platform reached 39.40 million, of which taobao.com sellers for 37.79 households, businesses on the B2B platform is about 1.6 000.2013 Ali platform sales of agricultural products, an increase of $112.15 \%$, an increase of 1688 platform 301.78\%, 2013 in taobao.com platform, snacks or nuts specialty items for the biggest sales of agricultural products category, and fresh related categories maintained the fastest growth rate, an increase of $194.58 \%$ as the biggest selling single product.

\section{E-commerce logistics of Halal agricultural products}

Products logistics infrastructure is backward, logistics link loss, low efficiency, at present. Ningxia rural areas, especially in some mountainous rural areas, traffic inconvenience, agricultural logistics facilities are still very backward. In China each year about 1 tons of fresh fruits in the logistics process of decay, the loss rate is about $25 \% \sim 30 \%$ lacking of specialized technical equipment of agricultural transportation, information tracking service is not perfect, and is mainly to room temperature and natural logistics logistics.

Logistics enterprises are small, and their management ability and service level are low. There are many people in Ningxia, and logistics enterprises often appear blind in construction. Ningxia agricultural products logistics enterprise effective use of high-tech means, cannot be advanced hardware, software and management concept into the enterprise, thus cannot achieve the optimal allocation of resources and effective use; in the electronic commerce development driven by the agricultural product logistics enterprises such as bamboo shoots after a spring rain like emerge, but really suitable for fresh agricultural products it is almost zero.

E-commerce Logistics Personnel. China's electronic commerce Signature Law has been promulgated, but China is still in the stage of rapid development of e-commerce, many loopholes in the laws, which give criminals an opportunity to leave, bring a loss to producers and consumers. Foreign logistics development experience, whether the logistics practitioners have higher logistics knowledge and experience, will directly affect the survival and development of enterprises, but at present our country in the aspects of logistics management, logistics planning, logistics research and other professional talent is very scarce. Ningxia is located in the western inland, logistics personnel is limited. 


\section{Ningxia Halal Agricultural E-commerce Logistics Development Strategy}

\section{Improve the environment of E-commerce logistics of Halal agricultural products in Ningxia.}

To speed up the Halal agricultural products logistics infrastructure construction of agricultural infrastructure construction. Including Halal Products, agricultural products wholesale market construction of Halal Halal agricultural products warehouse construction, transportation construction. Guided by the government, enterprises and individuals to supplement, increase capital investment, strengthen rural road construction; strengthen the construction of agricultural rural logistics warehouse, the development of distribution center, network, and information system construction accordingly.

E-commerce laws and regulations. The development of e-commerce and logistics of Halal agricultural products cannot be separated from the government's macro-control and legal support. The Halal e-commerce laws and regulations are the reliable guarantee for the standardization and standardization of the E-commerce and logistics of Halal agricultural products. Perfect Halal agricultural e-commerce laws and regulations, to reduce the fluctuation of the policy of Halal E-commerce of agricultural products, and perfecting the laws and regulations of e-commerce can also provide legal support for the government macro-control Halal E-commerce of agricultural products.

Develop and strengthen the main logistics enterprises of agricultural products. Modern logistics enterprise logo is one of the logistics information, logistics information in the commercial, logistics information collection of data and code, logistics information processing electronic and computer storage and logistics information digitization; through system innovation, innovation, foster and strengthen the agricultural product logistics enterprises, to make it to the scale operation, mechanization and automation, informatization and digitalization development; in addition, should vigorously support and development of third party logistics.

Focus on Training E-commerce Logistics Talents in Ningxia. E-commerce logistics involves many subjects and needs compound talents. The cultivation of such talents mainly depends on the cooperation between universities and government enterprises in Ningxia. the government should give support in terms of capital and the school of electronic business logistics research, make the electronic commerce logistics personnel can enjoy preferential policies in the enterprise and university cooperation; the combat platform, students will learn the application of theory to practice, the accumulation of knowledge in practice, and constantly improve their professional quality; in addition, the development of electronic business logistics, not only need to universities, government and enterprises, but also the majority of members of society, new ideas, actively accept the . E-commerce sales model in the information age.

\section{Innovation of E-commerce logistics mode of Halal agricultural products in Ningxia.}

B2B E-commerce platform model of Halal Products in Ningxia. Electronic commerce refers to electronic commerce between enterprises. Through the construction of a similar to the Alibaba, but the franchise Halal agricultural products of Ningxia platform, build comprehensive virtual markets including Ningxia Halal fresh agricultural products, agricultural products, and Halal Ningxia characteristics. In comparison with existing e-commerce models and combined with the actual analysis, this platform is in line with the characteristics of China's agriculture. Only provide a platform for services, not directly involved in the transaction, as the third party charge commissions and advertising fees to provide professional services for customers.

Ningxia Muslim agricultural products online group buying model. Farmers or agricultural production enterprises can use the group purchase website, such as the U.S. group, handle, Baidu group purchase and so on, agricultural products group purchase information, or consumer buying and selling enterprises can participate in group purchase, and online payment, the third party logistics.

\section{Conclusions}

At present, the conditions of applying e-commerce to the circulation of agricultural products are gradually mature. Create a B2B E-commerce platform in Ningxia, on the one hand can reduce the logistics, reduce logistics costs and loss, on the other hand can resolve the network level is not high, to provide convenience for farmers, bring benefits to farmers. Through this platform, the supply and demand sides can quickly deal, can 
greatly save time, improve the turnover the rate of. Ningxia agricultural product on the network group purchase stage, can not only meet the public demand for agricultural products, but also increase the income of the farmers. For some Ningxia characteristics of agricultural products can easily adopt from the Internet.

\section{Acknowledgements}

This work was supported by the Provincial Key Laboratory of E-commerce of Ethnic Information of Northwest Minzu University and Comprehensive experimental teaching center in Economics(Grant No. 2016XJSYJXSF2X-01-10019109) and by Special Funds for Undergraduate Teaching Reform by Central University of Northwest Minzu University (Grant No:10019153).

\section{References}

[1] Wang hongwei, analysis of the logistics mode in the e-commerce environment, China Commerce, 2(2010) 104-105.

[2] Shiyan, the analysis of development environment of electronic commerce in China, Journal of Library, 2 (2016) 186-192.

[3] Wang guiping, Discussion on the logistics operation of China's agricultural products under the e-commerce environment, Shandong Agricultural Science, 2(2011)115-119.

[4] Li hong, Chen ruling, Research on logistics development of agricultural products port in northwest ethnic region. Logistics Engineering and Management, 6 (2011) 15-16.

[5] Li zheng, issues of agricultural e-commerce logistics development in China. Journal of Logistics Technology, 7 (2010) 8-10.

[6] Tang Michael, Perfect China's agricultural e-commerce logistics research. Journal of Tongling College, 4 (2011)13-14.

[7] Li jihua, Exploration of the problems of China's agricultural e-commerce logistics. Modern Economic Information, 5(2011) 86.

[8] $\mathrm{Su}$ xiaowen, Characteristics of logistics management, problems and countermeasures, Business Era. $3(2010) 40-41$. 